\title{
Breast Uptake of Ga-68 DOTA-TATE in a Nursing Woman with Net Diagnosis
}

\author{
NET Tanılı Emziren bir Kadında Ga-68 DOTA-TATE Meme Tutulumu
}

\section{Sabire Yilmaz Aksoy ${ }^{1}$, Betül Vatankulu² ${ }^{2}$ Elife Akgün ${ }^{2}$, Metin Halac ${ }^{2}$, Levent Kabasakal ${ }^{2}$, Kerim Sönmezoglu ${ }^{2}$}

${ }^{1}$ Ankara Ataturk Training and Research Hospital, Department of Nuclear Medicine, Ankara, Turkey

${ }^{2}$ Istanbul University, Cerrahpasa Medical Faculty, Department of Nuclear Medicine, Istanbul, Turkey

\begin{abstract}
Neuroendocrine tumors are heterogenous group of tumors that expresses somatostatin receptors on their cell surfaces. PET/CT with Ga-68 labeled somatostatin analogues has been used as an important imaging modality in the NETs. It's important to know normal biodistribution of radiotracer to avoid misinterpretation. We report physiologic breast uptake of Ga-68 in a nursing patient.
\end{abstract}

Key Words: Ga-68, DOTA-TATE, PET/CT, lactation

Received: 05.25 .2016
Accepted: 06.12.2016
ÖZET

Nöroendokrin tümörler, yüzeylerinde somatostatin reseptörü exprese eden heterojen bir tümör grubudur. Ga-68 işaretli somatostatin analogları ile yapılan PET/BT, NET'lerde önemli bir görüntüleme modalitesi olarak kullanılmaktadır. Radyoaktif ajanın normal dağılımının bilinmesi yanlış yorumlamaların önlenmesi açısından önem taşımaktadır. Biz bu vakada emziren bir hastada fizyolojik Ga-68 meme tutulumunu bildirdik.

Anahtar Sözcükler: Ga-68, DOTA-TATE, PET/BT, laktasyon

Geliş Tarihi: 25.05 .2016

Kabul Tarihi: 12.06 .2016

\section{INTRODUCTION}

Neuroendocrine tumors (NET) arise from the neuroendocrine cells and express somatostatin receptors (SSTRs). These tumors can originate from any organ through the body derived from the neural crest. Conventional imaging methods have limitations in these tumors because of small tumor size, variable location and low metabolic rate (1).

Somatostatin receptor scintigraphy (SRS) is an important imaging method in neuroendocrine tumors. Although SRS allows for whole-body imaging, there are some drawbacks such as imaging of organs with high physiological uptake and suboptimal physical resolution of the isotopes (2). Recently, PET/CT with Ga-68 labeled somatostatin analogues has been developed and has shown clear advantages including improved spatial resolution and pharmacokinetics (3).Knowledge of normal biodistribution of radiotracer is important when interpreting the PET/CT images. The pituitary, salivary glands, thyroid, liver, spleen, adrenals, pancreas, kidneys, ureters, and bladder are the organs that show physiological tracer uptake. However, up to our knowledge, physiologic breast uptake of Ga-68 in a lactating patient has not been reported previously. Here, we report bilateral breast uptake of Ga-68 DOTA-TATE in a nursing patient with NET diagnosis.

\section{CASE REPORT}

A 36-y-old female with a mass lesion at the junction of pancreatic body and tail was diagnosed as neuroendocrine tumor (Ki-67:1\%). PET/CT with Gallium-68 (Ga-68) performed for staging demonstrated very intense tracer uptake at the pancreatic lesion (SUVmax: 48,9) (Figure 1, arrow). There was also bilateral breast uptake in the patient who had been breast-feeding for 1 year. 


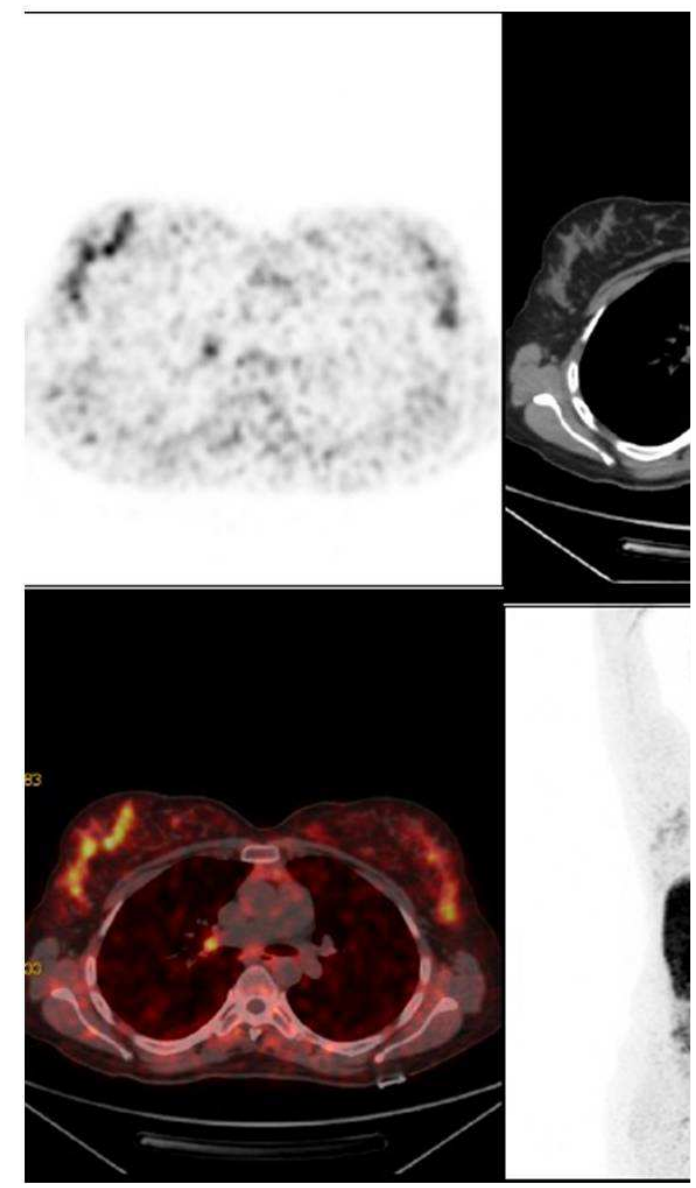

Figure 1. A 36-y-old female patient, 1 year postpartum, with NET diagnosis underwent Ga-68 DOTA-TATE PET/CT for staging. Axial PET, CT, fusion and MIP images revealed bilateral breast uptake of Ga-68 DOTA-TATE which was more prominent on the right side. There was also pancreatic lesion with intense Ga-68 accumulation (arrow).

\section{DISCUSSION}

Uptake of 18-fluorodeoxyglucose during breast-feeding is well documented (4-7). However, as far as we know, physiologic breast uptake of Ga-68 in a lactating patient has not been reported previously. The Ga-68labeled somatostatin analog Ga-68 DOTA-D-Phe1-Tyr3-octreotate (Ga-68DOTA-TATE) expresses increased affinity for somatostatin receptors-2 (SSTRs 2) (3). The physiologic uptake of DOTA-TATE was seen in the pituitary, salivary, thyroid glands, spleen, liver, adrenals and kidneys and excretory activity in the urinary tract. Kagna et al. demonstrated that the most common location of 68Ga-DOTA-NOC-avid sites other than NET was in small lymph nodes, followed by prostate, uterus, breasts, lungs, brown fat, musculoskeletal system, and other sites, including oropharynx, pineal body, thymus, aortic plaque, genitalia, surgical bed, and subcutaneous granuloma. They found 29 sites of diffuse 68Ga-DOTA-NOC uptake in the breasts in 14 of the 96 female patients with SUVmax range of 0.8-2.7. Low and variable expression of SSTR 2 has been reported in breast tissue unaffected by disease (8). In our case, we demonstrated Ga-68 DOTA-TATE uptake in the bilateral breasts in a nursing patient newly diagnosed with NET. GA-68 DOTATATE is excreted into breast milk and breastfeeding should be interrupted and can be restarted when the radiation dose to the child would be lower than $1 \mathrm{mSvin}$ order to minimize radiation exposure to a breastfed baby. Until that time, lactating women should discard breast milk approximately for 12 hours after injection of Ga-68 DOTATATE administration (9).Although tracer uptake of breast during breast-feeding is a well known phenomenon, this is the first case imaged by Ga-68 DOTA-TATE $\mathrm{PET} / \mathrm{CT}$.

Conflict of interest

No conflict of interest was declared by the authors
1- Ramage JK, Davies AH, Ardill J, Bax N, Caplin M, Grossman A, et al. Guidelines for the management of gastroenteropancreatic neuroendocrine (including carcinoid) tumors. Gut. 2005;54(Suppl 4):iv1-16

2- Kowalski J, Henze M, Schuhmacher J, Mäcke HR, Hofmann M, Haberkorn U. Evaluation of positron emission tomography imaging using [68Ga]-DOTA-D Phe1-Tyr3- octreotidein comparison to [111/n]-DTPAOC SPECT.First results in patients with neuroendocrine tumors. Molecular Imaging and Biology, 2003;5:42-8

3- V. Ambrosini, D. Campana, P. Tomassetti, G. Grassetto, D. Rubello, S. Fanti. PET/CT with 68Gallium-DOTA peptides in NET: an overview. European Journal of Radiology,2011;80:116-9

4- Hicks RJ, Binns D, Stabin MG. Pattern of uptake and excretion of (18)F-FDG in the lactating breast. J Nucl Med. 2001;42:1238-42.

5- Yasuda S, Fujii H, Takahashi W, Takagi S, Ide M, Shohtsu A. Lactating breast exhibiting high F-18 FDG uptake. ClinNucl Med. 1998 Nov;23:767-8.

6- Aksoy SY, Görtan FA, Özdemir E, Türkölmez Ş, Halac M, Sonmezoglu K. 18F-FDG PET/CT imaging of breast cancer in a lactating woman. Rev Esp Med Nucl Imagen Mol. 2016;35:135-6.

7- Ko KH, Jung HK, Jeon TJ. Diffuse intense 18F-FDG uptake at PET in unilateral breast related to breastfeeding practice. Korean J Radiol. 2013;14:400-2.

8- Kagna O, Pirmisashvili N, Tshori S, Freedman $\mathrm{N}$, Israel $\mathrm{O}$, Krausz $\mathrm{Y}$. Neuroendocrine tumor imaging with 68Ga-DOTA-NOC: physiologic and benign variants. AJR Am J Roentgenol. 2014;203:1317-23

9- Virgolini I, Ambrosini V, Bomanji JB, Baum RP, Fanti S, Gabriel M, Papathanasiou ND, Pepe G, Oyen W, De Cristoforo C, Chiti A. Procedure guidelines for PET/CT tumour imaging with 68Ga-DOTA-conjugated peptides:68Ga-DOTA-TOC, 68Ga-DOTA-NOC, 68Ga-DOTA-TATE. Eur J Nucl Med Mol Imaging 2010;37:2004-10 